\title{
TRANSLATING A FIGHT SCENE IN PETRONIUS' SATYRICON
}

\author{
Sarah Ruden, University of Cape Town
}

Ancient mock-epic or mock-heroic literature illustrates several important problems in the translation of Latin and Greek, but most importantly the problem of style and tone. The recently available option of searching in a computer database for words and phrases wherever they occur in Classical literature has given translators their first real opportunity to do the necessary research on style and tone within reasonable lengths of time; in the past, even when the best dictionaries and concordances where at hand, hours of searching through them could in some cases be necessary to determine for certain the flavor of even a few words, so that for translation of all but the shortest works of literature thorough research was simply impractical. Technological shortcuts will probably contribute to the raising of translation standards and the production of texts accurate and attractive enough even for an academic marketplace where competition with the Classics has grown enormously during the past few decades.

In writing my dissertation on humor in the Roman novelist Petronius, 1 a dissertation in which style and tone were major concerns, I was fortunate enough to have access to all of Latin literature on computer disk, 2 as well as to the archives of the Thesaurus Linguae Latinae, the comprehensive dictionary of Classical Latin, which now, about eighty years after work on it began, is complete up to the volume for the letter "P". With these resources, I was able to identify by examples some major translation pitfalls and challenges. They illustrate some of the most problematic and at the same time most delightful features of Petronius, and also some general issues in reading and translating ancient literature, particularly in translating its humor, which is notoriously difficult to reproduce.

The fragments of Petronius' novel The Satyricon contain the picaresque adventures of the narrator Encolpius (a Greek word for "crotch") and his companions in the South of Italy. The novel is set, and was probably written, around A.D. 60, during the reign of Nero. The story is raucous and farcical, but also elegantly written and highly learned. These qualities stand in especially stark contrast to each other in the fight scenes in the novel Chapters 95.4-9, 108.3-13, 136.4-9 - where the style is what I would call "mock epic" or "mock heroic". In this essay I discuss translation issues in terms of the practical problems I have encountered in translating the first of these scenes, the text of which I reproduce, along with my own translations, a basic and more finished one, in an appendix following the discussion.

"Mock epic" and "mock heroic" are in reality only convenient shorthand terms for the style of this scene. The scene does contain lofty language of battle and conflict, but this

\footnotetext{
$1 \quad$ S. Ruden, 1993.

2 Thesaurus Linguae Latinae, 1991.
} 
language was common, in its basic form (there were some vocabulary and syntax differences, of course), to all of Roman higher literature - not only epic poetry, but also history and tragedy, and even philosophy and forensic speeches. The terms "mock epic" and "mock heroic" can be useful shorthand in another way as well, in that they mean both lofty language for low or trivial happenings, and lofty language interrupted by low language. Pope's Rape of the Lock (which he calls "a heroi-comical poem") is a good example of the first kind of contrast: a society squabble is narrated in lofty language, and even trivial objects and actions are described with euphemisms and circumlocutions whenever possible. The opening lines, in fact, describe rather explicitly the level of the style and of the content:

What dire offense from amorous causes springs,

What mighty contests rise from trivial things,

I sing - This verse to Caryll, Muse! is due ...3

Another example which I cannot resist mentioning is a version of the nursery thyme "Jack and Jill" in mock heroic style by the great Classical scholar A.E. Housman. The poem is about fifty lines long and contains couplets as "The prudent fair, of equilibrium vain I Views, as he falls, the rotatory swain." 4 The second kind of mock epic contrast listed above, high language interrupted by low language, is a favorite technique of Aristophanes, as these lines from Lysistrata show, in a scene in which the heroine is persuaded to acknowledge the trouble she is having enforcing the sexual strike on the part of the Greek wives:

Chorus: What ails thee? Tell thy friends what grieves thy heart.

Lysistrata: Shameful to say, yet burdensome to hide!

Chorus: Hide not from me the evil which you bear.

Lysistrata: We need, alas, some screwing, in a word.

(712-715, my translation)

Both of these methods of mock-heroic humor (language-content contrast and languagelanguage contrast) are often combined, as Aristophanes combines them in this passage (the situation, women going on sexual strike, is crude and trivial, and the intrusion of an obscenity - "screwing" is a mild translation of it - only adds a language-language contrast to the language-content contrast already there). Petronius uses both types of contrast in his fight scenes. What makes the Petronius passages unusually interesting, but has been missed by all of his translators so far, is the dense interweaving of different levels of language which occurs in almost every sentence, and the almost equally dense interweaving of reminders of the absurd and sordid situation which the lofty language in part masks. Changes in the level of style and the intrusion of crude imagery must have been funny to Petronius' original readers, but there are no build-ups or punch-lines (as in the Aristophanes passage cited ahove) to create plainer humorous patterns. The ambitious translator must go through the Latin literally word by word, testing the tone and level of each one, and hope that what he can put together in English is funny without being too jarring. It is in fact possible to find examples of such a balance in English prose, as in a fight scene by the American humorist James Thurber:

3 From The Norton Anthology of Poetry, 1983.

4 From A.E.H.: Some Poems, Some Letters, and a Personal Memoir by his Brother, edited by Laurence Housinan, 1937. 
Their apartment, before they began to take it apart, had been quietly and tastefully arranged, but it was a little hard to believe this now, as he stood there by the fireplace, using an andiron to bat back the Royal Doulton figurines she was curving at him from her strongly entrenched position behind the davenport. 5

I find especially effective the contrast between the words "quietly and tastefully arranged", which sound as if they come from a rather posh magazine, and "take it apart", which resemble a narration of a barroom brawl. The phrase "strongly entrenched position benind the davenport" is superb as well, because the language of the battlefield is applied to a scene set in a middle class living room, as the word "davenport" reminds the reader. I do not think that such writing can really be imitated, especially through the restrictive medium of translation, but a translator can nevertheless keep a collection of outstanding English passages in his mind, as a reminder of how demanding the work is that he has undertaken.

\section{II}

Against this background, I would like to discuss by examples in Satyricon 95.4-9 some of my own practical apporaches. (References are to the sections and lines numbers in the Appendix.) The action takes place in a lodging house. The landlord has come to the narrator's room, where the narrator has been noisily and rather destructively entertaining his new friend, the poetaster Eumolpus. The landlord's concern for the furniture and the payment of the rent angers Eumolpus and leads to a free-for-all, which the passage describes.

The contrast of the basic translation (B) and the revised translation (C) shows what general method I used. I researched some of the history and tradition of every Latin word but the most bland and common, and then I attempted to find English equivalents: archaic, lofty English words for Latin words which occur in higher literature, and in more serious and lofty contexts in general; and more colloquial English words for Latin words which occur in less formal literature and cruder contexts. For example, iaculatus est (A3) is a verb proper to higher literature, and especially to its battle scenes (the verb actually comes from the Latin word for "spear").6 I chose English "launched" for the revised translation (C3), since that word is more formal and technical than "threw" (B3). (Incidentally, Petronius achieves one of a number of bathetic effects by making a cheap and common object, a "jug", the thing the innkeeper "launches". More on the jug later.) An example of crude language is the word mulcant (A9; "were beating" in B10); I found that the Latin word was principally used in farcical literature, such as stage comedy, and for brawls, not battles, 7 and I rendered it as "were whacking" (C11), though there are many other possibilities. The word mulcant has a wonderfully silly effect here, and one cause is the neighbouring word exclusum, literally "shut out", a word which has the flavor of love poetry. The young lover is typically "shut out" (exclusus), of his mistress' house and lies on the ground and composes poetry to her - not an outstandingly serious situation, especially in the context of Roman values, but much more serious than the word mulcant.

5 "My Own Ten Rules for a Happy Marriage", reprinted in Vintage Thurber, edited by H. Thurber, 1963.

$6 \quad$ As at Lucan 3.568.

7 See, for example, Plautus Trin. 984.

8 As in Tibullus 1.2 
In the revised translation I rendered the phrase as "were whacking the forlorn poet" (C11), though this is fairly weak in its humor compared to the original phrase. Such variations of the level of language do not show up clearly in any of the published translations of Petronius, but the variations are now relatively easy to find through the use of a computerized lexicon - and English is certainly rich enough to allow a translator to reproduce them, though of course they will not have the naturalness or the inevitablesounding quality of an original text. Another source of my attachment to researching a translation word by word is that, as my Appendix shows, this practice pushes the translator closer to grammatical and syntactical equivalents of the Latin, as well as greater faithfulness of tone. Once someone has traced individual words, he does not want to let any of them go - he tries to find a way to incorporate all of them. If the translator does not in any way make a habit of dwelling on individual words, he tends to view the Latin on the level of sentences and even passages, and is willing to drop anything but what is essential for clarity.

But if distinguishing and rendering the contrast between levels of language in the passage is unproblematic, the contrast between language and content presents greater challenges. Distinguishing is not difficult, but rendering is. The imagery, of course, is impossible to reproduce. The Latin may mean "candlestick" (candelabrum, A4), and that may be the only sensible translation option, but the translator still fails, because the Roman reader had an accurate picture of the object in his mind, whereas if the modern reader has any picture in his mind at all, it is the wrong one. But the problem of imagery is only one illustration of the bane of translators of humor, which is that humor tends to be attached to the ephemeral details of a culture, and to depend on the audience's membership and full participation in that culture. In America, for example, there is a group of children's rebellious comic songs based on "The Battle Hymn of the Republic". One song has a chorus of

Glory, glory, Hallelujah! Teacher hit me with a ruler.

I hid behind the door with a loaded forty-four ...

It is not only the rhyme which makes the designation of the gun as a "forty-four" important. The unspecific word "gun" would be much less funny in this context even if it did rhyme. Likewise in Petronius 95.4-9, one of the important objects is not merely a "vessel", which would probably be the word used in tragedy, but an urceolus fictilis (A2), a small earthenware pitcher, a very specific object. How can any clear idea of this object be integrated into a translation? Such a situation is frustrating enough to cause a translator to abandon translating for rewriting, i.e., finding modern equivalents which he believes will evoke roughly the same response in his own culture as the items in the original passages evoked in the author's culture. Not that all translators do not do this occasionally; the propriety of doing it is only a question of when and why and how it is done. For example, I feel justified in writing "wooden clogs" (C15) for soleis ligneis (A11) for the sake of specificity, since the Latin word soleae is more specific than the English "shoes".9 Even so, I know that the modern reader will have a different vision of "clogs" than the one Petronius intended for soleis. American readers will probably picture souvenir Dutch clogs with the toes pointing upward and possibly windmill or tulip designs in red enamel paint. I do, then, in a sense, lead people astray, but I do not think that I deserve to be cast into the sea with a millstone around my neck. On the other hand, writing "Coke bottle" for the Latin urceolum fictilem, instead of the word "jug" (which I eventually chose), would be going too far and deliberately forfeiting the reader's trust. As an undisguised escape from 
translation, there is nothing wrong with running amok and simply responding to the text. This was Ezra Pound's program in "Homage to Sextus Propertius", in which, for instance, he uses the words "deal-wood horse" for the Latin words for "fir-wood horse", meaning the Trojan horse. 10 But once the scholar has run amok and had his fun, the original text is still there, with the ghost of the author hovering above it and demanding to be heard.

Of course not all of the language/content contrast in the passage is as problematic as what I have cited. The contrast becomes much more accessible for the modern reader when the attention of the narrator centers on the anus lippa, the bleary-eyed old woman (A11ff., B12ff. and C13ff.): she is actually not "belted" (as in my basic translation), but "girded up" (praecinctus in its most basic usage applies to warriors going into a battlel1); and she does not "stand" on her unmatched wooden shoes, she is "mounted" on them (impositus is a normal way, in higher literature, of indicating that someone is mounted on a horse12). She does not "sick" her dog, but "urges him on" in the manner of a commander urging on his troops (there are several examples in history and epic poetryl3). The imagery in the modern reader's mind may not be precise (what does her nightgown look like, for example?), but he can still picture an old woman going into a battle, which is in reality an indoor brawl.

The problems a translator has in trying to reproduce a culture in his readers' minds are by no means limited to material culture. I can demonstrate this with two essentially untranslatable linguistic jokes in this passage. The first joke depends on the intense relationship with literary style which was common among Petronius' original readers. In the first sentence of the passage, palma excussissima looks very odd. If translated in the most obvious way, it literally means "with most thrown/most brandished palm". The verb excutere, from which the participle excussissima comes, means "throw" or "brandish", and the verb is used of a weapon in most places where it occurs (incidentally, it occurs often in higher literature14); it seems that the verb is employed in such a strange way here because Petronius is fond of commenting implicitly on changes in Latin which occurred during and a little before his lifetime. In the case of excutere, two flashy, rather untraditional authors, Ovidis and Seneca the Younger, 16 use a new, recherché meaning, "extend", and apply this meaning to the arm as it launches a weapon; the reason I believe that Petronius is referring to this new usage is that he employs the perfect passive participle and applies it to a part of the body as these authors do, but makes that part of the body a weapon, as weapons are the object of the verb in earlier authors. Petronius, it appears, cannot be serious in doing this, since he uses the superlative, literally "most extended", and the superlative is quite unusual for a participle which has not passed into common use as an adjective; this one has not. The purpose of the superlative in this instance must be to lend more irony to the word - to give a suggestion of size and force to such a small and relatively harmless object as the palm of the hand. I translate: "dealt the man a full mighty smack in the face", but of course there is no way to replicate the ideas about language and literature which the Latin phrase contains.

From Collected Shorter poems by Ezra Pound, 1952.

11 Petronius himself plays on this meaning in 83.10.2.

12 Cf. for example Livy 2.64.10.

13 For example Vergil Aen. 11.730.

14 Vergil, Livy, Statius, etc., typically in battle scenes.

15 Her. 4.43.

16 Ben. 2.6 
The second of the untranslatable jokes is supercilium suum vindicat (A5, B5-6 and C6-7), a play on words. Supercilium means literally "eyebrow", figuratively "pride": Eumolpus avenges both, since he has been hit in the forehead. How can this be translated into English? I rendered it quite inadequately as "avenging his haughty eyebrow". As at several points even in this short passage, I must live with my helplessness. But one of the reasons I continue translating is that it is somewhat like being an undertaker as opposed to a doctor: not a great deal is even expected of me.

\section{III}

To be less morose in conclusion: now that there is both opportunity and need for better translation, I am certain that interest in and support for this activity will grow among the community of Classical scholars, though the low status of translation is in part unavoidable, because of the way we are trained. Some of us, while we were learning to read Latin and Greek, were actually forbidden to consult translations, in 'case we should come to use them as crutches. This strictness is understandable and perhaps necessary, but it has the unfortunate side-effect of encouraging snobbery in the form of the belief that only an original text is worth reading, and that only those who learn the original language deserve detailed and meaningful access to the original text. One professor, in fact, told us, "Reading a translation is making love with mittens on", and we accepted this; we were flattered that he had singled us out implicitly as the elite group able to deal with the Classics directly. We did not consider, in crude terms, that a discipline which isolates itself through snobbery is doomed; or, in less crude terms, how much better an experience of a work of art a person has if he shares that experience in the spirit of finding out more himself. Perhaps reading most translations is making love with mittens on, but reading Latin and Greek and making no contribution to translation is masturbating.

\section{BIBLIOGRAPHY}

Allison, A. et al. (eds.) 1983. The Norton Anthology of Poetry. (3rd ed.) New York: W.W. Norton and Company.

Housman, L. 1937. A.E.H.: Some Poems, Some Letters, and a Personal Memoir by his Brother. London: Jonathan Cape.

Mueller, K., and W. Ehlers, 1983. Petronius, Satyrica: Schelmenszenen. (3rd ed.) Munich: Tusculum.

Pound, E. 1952. Collected Shorter Poems. London: Faber and Faber.

Ruden, S. 1993. Toward a Typology of Humor in Satyricon of Petronius. Doctoral dissertation, Harvard University. Ann Arbor, Michigan: University Microfilms.

Thesaurus Linguae Latinac 1991 (CD ROM \#5.3). U.S.A.: The Packard Institute.

Thurber, H. (ed.) 1963. Vintage Thurber. London: H. Hamilton. 


\section{APPENDIX}

\section{A. Latin Text}

1 exclamat Eumolpus 'etiam minaris?' simulque os hominis palma excussissima pulsat. ille + tot hospitum potionibus liber + urceolum fictilem in Eumolpi caput iaculatus est solvitque clamantis frontem et de cella se proripuit. Eumolpus contumeliae impatiens rapit ligneum candelabrum sequiturque abeuntem et

5 creberrimis ictibus supercilium suum vindicat. fit concursus familiae hospitumque ebriorum frequentia. ego autem nactus occasionem vindictae Eumolpum excludo redditaque scordalo vice sine aemulo scilicet et cella utor et nocte.

interim coctores insulariique mulcant exclusum et alius veru extis stridentibus

10 plenum in oculos eius intentat, alius furca de carnario rapta statum proeliantis componit. anus praecipue lippa, sordidissimo praecincta linteo, soleis ligneis imparibus imposita, canem ingentis magnitudinis catena trahit instigatque in Eumolpon. sed ille candelabro se ab omni periculo vindicabat.

(95.4-9)17

\section{B. Basic Translation}

1 Eumolpus cried, "You're actually threatening me?" and at the same time hit the man's face with the flat of his hand. The landlord, +loosened up by a good deal of drinking with his lodgers + , threw an earthenware pot against Eumolpus' forehead and rushed out of the room to the sound of wounded cries. Eumolpus,

5 not tolerating this insult, snatched a wooden candlestick and followed, avenging his eyebrow with a rain of blows. All of the slaves in the household ran up, along with a crowd of drunken lodgers. I took this occasion for revenge, locked out my quarrelsome acquaintance, and made the room and the evening mine again.

10 In the meantime, cooks and lodgers were beating Eumolpus. One man was jabbing at the poet's eyes with a spit full of hissing meat, and another snatched a fork from the sideboard and took up the stance of a warrior. A bleary-eyed old woman, however, dressed in a very dirty belted nightgown and standing on unmaiched wooden shoes, outdid them: she had an enormous dog on a chain and

15 was sicking it at Eumolpus. But he used his candlestick to defend himself from every danger.

\section{Revised translation}

1 Eumolpus cried, "You go so far as to threaten me?" and at the same moment dealt the man a full mighty smack in the face. The landlord, +loosened up by a good deal of drinking with his lodgers + , launched an earthenware pot at Eumolpus' head and laid the forehead open - the poet screamed - then took

5 flight from my hotel room. Eumolpus, loath to bear this affront, snatched a wooden candlestick and followed, avenging his haughty eyebrow with many and frequent blows. The noise, however, summoned an auxiliary force consisting of slaves of the household, and the drunken lodgers assembled as well. I seized the occasion for vengeance, locked the pain in the ass out, and made the room

10 and the evening mine again.

In the meantime, cooks and lodgers were whacking the forlorn poet. One man was jabbing at Eumolpus' eyes with a spit full of hissing meat, and another snatched a fork from a sideboard and took up the stance of a warrior. A particular threat, however, was a bleary-eyed old woman, girded up in a most

15 grubby nightgown and mounted on unmatched wooden clogs: she had a dog of huge size on a chain and was urging it on against Eumolpus. But he defended himself with his candlestick against every peril.

17 The Latin text is from K. Müller and W. Ehlers' Petronius, Satyrica, Schelmenszenen, 3rd edition, Munich, 1983. 